\title{
Presentation Copies in the Sandburg Library
}

\author{
By JOHN T. FLANAGAN
}

IN 1956 the University of Illinois acquired the library of Carl Sandburg. The collection included, first of all, the works of Sandburg himself, original editions of his verse and prose, as well as translations into Swedish, French, Spanish, Portuguese, Burmese, and other languages. There are numerous volumes to which Sandburg contributed prefaces or forewords, brochures, pamphlets, and copies of magazines containing articles or poems. Included too are hundreds of letters to Sandburg, typescripts and galley proofs of the voluminous Lincoln biography, clippings, lists, notes, annotated excerpts from various periodicals, bound magazines, federal documents, memoirs, and histories. Not all the items are strictly literary since the bulk of the material is swelled by photographs, scrapbooks, phonograph records, a collection of postage stamps with a portrait of Lincoln, an album of Lincoln pennies, souvenirs, and memorabilia. But one of the most interesting sections of the library consists of the books sent to Carl Sandburg as gifts, almost always inscribed by the authors and occasionally annotated by the recipient himself.

Every author attracts to himself as a magnet does steel filings the literary work of others, the books of friends as a matter of course but also publishers' gifts, the volumes of specialists in the same field, presentation copies sent by contemporary celebrities, and invariably the fledging work of young poets and novelists sent through admiration and pride, or (so they sincerely say) in the hope of criticism. Probably no one is so aware of the enormous amount of verse published by private presses or as prestige items by commercial presses as the established poet who has himself won
Mr. Flanagan has been Professor of English at the University of Illinois, Urbana, since 1949. He was a Guggenheim Fellow in 1943-44; Newberry Fellow in 1944, and Fulbright lecturer at Bordeaux in 1952-53.

success in print and very likely on the lecture platform. His weekly mail swells his library shelves with thin, often handsome, and generally unwanted volumes.

Presentation copies in the Sandburg library are curiously miscellaneous. There are a large number of high school annuals, sometimes dedicated to Sandburg but more often including a few lines from a Sandburg poem which are printed before the endless succession of photographs of the graduates. The collection includes a number of copies of Good Reading, a bibliographical list; a teaching manual from the Altoona, Pennsylvania, school system; a heavy and dull tome entitled The Forest Preserves of Cook County Illinois (Chicago, 3d ed., 1921); a book on health entitled The Therapeutics of Activity (Chicago, 1916); and a translation from the Italian, The Pirotechnia of Vannoccio Biringuccio (1942). One of the more curious items is a copy of the 1928 Model "A" instruction book issued by the Ford Motor Company and autographed by Henry Ford on September 23, 1928. The flyleaf bears the following note:

Henry never before had been asked to sign a manual-and I said it would give luck to the new car I was driving from Dearborn to Harbert-

\section{C.S.}

But the most unusual book is a volume certainly never listed in the catalog of the Library of Congress, a heavily boxed 
item with the label "Kentucky History Old Forester Ed. Vol. I" stamped on the spine and identified as the 1870 work of an "author" named George Garvin Brown. The curious reader who took this down from the shelf discovered immediately that the "book" was simply a false front for an unopened bottle of Old Forester Kentucky Bourbon, 100 proof, complete with glasses. It must be added that by administrative ukase this item has since been removed from the collection.

Because of Sandburg's long association with Chicago as newspaper reporter and feature writer, it is natural to find a number of books about the Windy City among the presentation items. Thus Nelson Algren, sending a copy of Chicago: City On the Make (1951), inscribed his gift:

for Carl Sandburg,

who loved the girl called Chicago first, best and truest of all.

John Drury, a Chicago newspaperman, wrote on the flyleaf of his Chicago in Seven Days (1928), "To Carl Sandburg, Your poetry first opened my eyes to Chicago, Carl." When Drury later published his Old Chicago Houses (1941), he dedicated the book to Sandburg, "whose poems were beacons illuminating new paths to me." The Chicago surgeon Max Thorek, sending an inscribed copy of his autobiography, A Surgeon's World (1943), wrote: "From a tyro in writing to a master Carl Sandburg In appreciation of his gifts particularly his Americanism." Richard Henry Little, in 1930 the conductor of the Chicago Tribune column "A Line O'Type or Two," presented Sandburg with a copy of the annual entitled The Linebook. One of the most sincere of these tributes came from Ruth McKenna (Mrs. Mayer) in the form of a letter attached to a copy of Chicago These First Hundred Years (1933).

\section{Dear Mr. Sandburg,}

I am sending you a small book which I have written. My first book.
I am sending it to you because five lines of your poem "Smoke and Steel" have been a sort of window through which I've looked at my subject.

These lines are:

"A bar of steel-it is only

Smoke at the heart of it, smoke and the blood of a man.

A runner of fire ran in it, ran out, ran somewhere else,

And left-smoke and the blood of a man

And the finished steel, chilled and blue."

Although, besides "Smoke and Steel" I've enjoyed your other poems and your prose, the five lines just quoted have meant most to me. Perhaps they've meant more than anything else I have read. So I'm one of the many thousands who sincerely thank you for them.

They are at the head of my book. I hope you'll find the pages which follow somewhat of a credit to them.

Any newly published Lincoln book as a matter of course found its way to the Sandburg library shelves, often with an appreciative tribute scribbled on the end pages or title page. Ida M. Tarbell sent a copy of In the Footsteps of the Lincolns (1924), with the greeting, "To Carl Sandburg from His Admiring Friend." In the same year the great Lincoln collector Oliver R. Barrett presented Sandburg with a copy of a reprint of Lincoln's last Springfield speech in the 1858 campaign, inscribed "To my good friend Carl Sandburg." Emanuel Hertz, author of Abraham Lincoln, The Tribute of the Synagogue (1927), remarked in his presentation copy, "To Carl Sandburg to whom all Lincoln lovers are indebted." Paul M. Angle, compiler in 1930 of New Letters and Papers of Lincoln, was particularly appreciative of past encouragement. He wrote: "To Carl Sandburg, who has said more kind words about this book than it deserves." Margaret Leech (Mrs. Ralph Pulitzer), then at work on her notable Reveille in Washington, was moved by her enthusiasm for The War Years to write on November 15, 1939:

For four years, I have steadily explored the period in preparation for a book, now near- 
ing completion, on the city of Washington during the Civil War. New light on the capital therefore came to me with especial pleasure; though scarcely less, I think, than the fascination of getting familiar events transmuted through a vivid and keen intelligence.

The distinguished biographer of Robert E. Lee sent Sandburg a reprinted editorial from his Richmond News Leader on March 26, 1950, and commented:

To Carl Sandburg

who may smile at the hexameters hidden in the prose form, but he will understand the sentiment, I know, as surely as he will the affection of

\section{Douglas Southall Freeman}

The late Professor James G. Randall, long an intimate friend of Sandburg, presented a revised version of his Constitutional Problems Under Lincoln (1951), and wrote:

\section{Dear Carl:}

There's only one Carl Sandburg, so I'd better quit wishing I could write like you.

You don't have to read all of this obese tome, but in the "Foreword" you may find some things we have talked about.

One of the warmest messages of gratitude came from Roy P. Basler, who inscribed a copy of his edition of Abraham Lincoln: His Speeches and Writings in 1946 as follows:

For Carl Sandburg - to whom I owe many thanks for kind words when I sent him the manuscript of The Lincoln Legend more than a decade ago and for encouragement through the years. May his spirit lighten the load and light the way for Americans forevermore!!

Undoubtedly the most interesting inscriptions in the collection appear in the books of successful creative writers with whom Sandburg had professional or personal contact. Thus on February 12, 1920, John Drinkwater sent a copy of his Poems 1908-1919 addressed to Carl Sandberg [sic], "my friend on a slight acquaintance, and a poet who has helped and is helping to express America." Wit- ter Bynner inscribed a copy of Cake (1926), from Santa Fe:

To Carl-

a bite of cake-in which I hope

he'll find a bit more than the bite-

Norman Corwin wrote on the flyleaf of They Fly Through the Air with the Greatest of Ease (1939):

To Carl Sandburg,

Whose verse contracts no rust,

Whose odes are bombproof,

And whose strophes will stand stout

Against all floods and famine, epidemic war, and general decaywhose poetry's the thing!

Christopher Morley was succinct in his remarks in a copy of Thunder On the Left (1925): "This is Carl Sandburg's and so am I." John Steinbeck sent one of ten specially bound presentation copies of The Grapes of Wrath on July 21, 1940, with the notation: "Carl Sandburg in memory of a good day and a bad horseshoe game. Received payment 15c." William Saroyan wrote in a presentation copy of his play The Time of Your Life (1939):

For Carl Sandburg

this small book humbly and in memory of another circus we once saw at Madison Square Garden-with admiration for the poet and man of the people, and with gratitude for the miracle of his reality.

An old friend and associate on the lecture stage, Lew Sarett, sent a copy of his book of poems, The Box of God (1922), with this inscription:

For Carl Sandburg:

Those first heartening words, your confidence in me, the quiet smokes together, the seeds you planted in what you thought at times was hostile soilthese, dear old Carl-I shall never forget.

A more formal response to Sandburg's request for one of his books came from J. E. Spingarn, for many years professor 
of comparative literature at Columbia University. He wrote on a page of The New Hesperides and Other Poems, 1911:

\section{Dear Sandburg:}

You asked for a copy of "Creative Criticism," but this too I dreamt of when I was climbing the ladder of my academic Purgatory, and some of it, here \& there, may interest you whenever beyond my cloister I saw visions of a happier America. It is a rare volume at least, for during the war I had the remaining copies destroyed.

New York,

April 1, 1923

Ever yours, J. E. Spingarn

In sending a copy of Sixteen Authors to One (1928), one chapter of which deals with Sandburg's work, David Karsner wrote:

For Carl Sandburg who does things, says things, writes things, and sings things that I like. Carl, I would love to live in the kind of America you would make, and of which you sing. Yours for always-

\section{David Karsner.}

On the margin of the same page Sandburg himself commented: "Dave is too kind."

The Colorado poet and newspaper editor, Thomas Hornsby Ferril, gave Sandburg copies of two volumes of his verse. In a copy of High Passage (1926), he wrote: "Dear Carl: Even if you'd rather have seven pounds of asparagus, I'm sending you this book anyway." Later, in the end pages of Westering (1934), he drew a picture of a guitarist perched atop a mountain peak and added these lines:

The grassy fetlocks of the bison drift Across another last meridian,

All westering. ... And I wish you \& your zither would climb aboard.

There are cottonwood songs to sing we haven't sung yet. Ever yours,

Tom-

Among the poets who sent volumes with minimal inscriptions were Arthur
Davison Ficke, William Alexander Percy, Jean Starr Untermeyer, Joseph Joel Keith, Helen Waddell, and the poet laureate of Kentucky, Cotton Noe. Sandburg might have taken special delight in MacKinlay Kantor's Turkey-In-the-Straw (1935), a collection of American ballads and primitive verse.

In her sole novel, The Border (1931), Dagmar Doneghy (Mrs. Joseph Warren Beach) wrote: "To Carl Sandburg with affection, in memory of long leisurely breakfasts, of a battered silver tea-spoon, and of the bits of cedar from the coffin of Abraham Lincoln." Gregory d'Alessio, a cartoonist for Collier's Weekly, sent a copy of Welcome Home! (1945), with the remark: "for Carl Sanburg [sic]: A fellow-obsessed at that delightful insanity - the Guitar-" Dr. Morris Fishbein inscribed a copy of The Medical Follies (1925), "To Carl Sandburg who has no other follies." And Waldo Frank wrote in a presentation volume of Our America (1919), "to Carl Sandburg whom I love."

Many of the books of Amy Lowell and Louis Untermeyer appear in the Sandburg library. Miss Lowell's comments are generally terse and conventional, but in a copy of Six French Poets (1916), she wrote: "Carl Sandburg, With sincere friendship and admiration"; and in her gift copy of her biography of John Keats she said simply, "Carl, with love from Amy." Untermeyer sent a copy of These Times (1917), paradoxically dedicated to Robert Frost, with the remark: "For Carl Sandburg fellow poet, \& what's far more important, fellow fighter." In 1919 Untermeyer inscribed a first edition of his Modern American Poetry, "for Carl, the worst correspondent in the Western World from Louis, the next worst." Another Untermeyer book, Including Horace (1919), a collection of satirical odes and parodies, reached Sandburg with the note, "This new brash but cordial impertinence." And in 1921 Untermeyer, sending a revised version of Modern American Poetry, announced it "with 
a truck-load of-damn these Anglo-Saxon inhibitions!-love."

Percy MacKaye was more solemn in his greeting. Sending a copy of The Mystery of Hamlet, the dramatic tetralogy about the Hamlet story before Shakespeare's tragedy began, MacKaye wrote: "To Carl Sandburg in the friendship of poetry from Percy MacKaye" and autographed the book at the Players Club, in New York City, December 7, 1950.

It is somewhat of an anticlimax to turn from such names to the multitude of poets who dispatched their little volumes, timorously but hopefully, either to Chikaming Goat Farm, Harbert, Michigan, or to Flat Rock, North Carolina. But their very number testifies to the perennial urge to express one's self in verse and also to Sandburg's fame. Volumes came from England, France, Cuba, Argentina, Brazil, Australia, and Japan, as well as from most of the states of the Union. A nisei sent a book from his detention camp in Wyoming, and a bank president mailed his from Pennsylvania. The poets were housewives, invalids turning to literature for a pastime, high school teachers, students, journalists, professional men. The majority of the books contain inscriptions of some sort, occasionally laconic, more often fulsome, and although the sentiments vary the writers usually express one of three attitudes. Most frequently they express their homage to Sandburg and affirm in some way their appreciation for his work. Again, they intimate that Sandburg has stimulated them to write their own verse so that they have incurred a special obligation to him. Finally, and this is often the most obvious of the motives, they beg for some comment, some evaluation of their work-for praise from Sir Hubert is praise indeed.

Thus Jean Catel sent a copy of Faux Sens, issued at Montpellier in 1927, with the inscription, "très cordial hommage à Carl Sandburg grand poète, de son frère modeste." And Alain Bosquet, poet and anthologist, wrote during war time in a copy of his L'Image Impardonnable (1942), "Au grand poète Carl Sandburg, l'hommage sincère d'un admirateur."

From Iowa in 1936 Van Meter Ames sent a copy of his Out of Iowa. From San Francisco came Sara Bard Field's The Village Festival in 1920 with the comment: "To Carl Sandburg - The gods bless him-for there is old wine in his new songs"; and from San Francisco also Melba Berry Bennett sent In Review, Poems (1946), with the note, "In memory of the delightful day we spent discussing poetry and goats!" Anne Kelledy Gilbert presented Sandburg with a copy of The Angel of the Battlefield (1928), from Washington, and an Episcopal minister from the Deep South, Charles Granville Hamilton, sent Mississippi I Love You (1941). The gift of Dr. Frederick Kettner, Life and Spirit (1948), was described by its author as a "biosophical poem." In 1932 Edna Nyquist compiled Pioneer Life and Lore of McPherson County, Kansas, and in the note accompanying the book describes her motives in undertaking the work. After receiving the book Sandburg made one of his rare marginal notations in such gift volumes: "I thank you Miss N, you done good . . . CS.”

A rather long note from a professor of moral philosophy, A. H. Lindsay, dated December 24, 1929, at Greeley, Colorado, and inscribed in a privately published pamphlet entitled Aphrodite and Other Sonnets might well illustrate the dual motives of praising Sandburg and winning some kind of personal recognition.

\section{Dear Mr Sanburg [sic]:}

I enclose with my compliments a copy of recent sonnets. I dare to send them knowing perhaps that there may not be any which would appeal to you. Yet, if there is one, or a line of one, which may appeal to you, I would be pleased.

I have read your poetry and I enjoy it; but, I frankly confess I prefer your polished products to "free verse." Not that I do not appreciate the real poetry in your "Grass," and "Chicago," "Cool Tombs," 
I do, but I like the "polish"

better. The moderns, no doubt, would not agree. There are schools of poetry, as there are, in theology, and all

are more or less dogmatists.

I would appreciate your frank

reaction to the contents of this copy. Yours sincerely,

\section{December 24th $1929 \quad$ A. H. Lindsay.}

Since Sandburg scorned sonnets because of their restrictive form, and habitually used free verse, one suspects that the writer never received an answer. But one still wonders what in Mr. Lindsay's mind represented Sandburg's "polish."

Among Sandburg's books are several volumes with no inscriptions and, for obvious reason, without authorial signatures. Two of them are by Adolph Hitler, a translation of Mein Kampf and My New Order. A third is the second, or 1856, Brooklyn edition of Walt Whitman's Leaves of Grass.

Sandburg's interest in and indebtedness to Whitman are well known. As a young man he read the Good Gray Poet faithfully and frequently; Whitman was his lecture topic when he first began to visit the small colleges of the Middle West and to talk about poetry; his own poetry from the very beginning reflects the loose rhythms, the colloquial diction, and the cumulative epithets of the nineteenth-century poet. Thus it is only natural that he would treasure an early edition of Leaves of Grass. Perhaps his most effusive tribute to Whitman is contained in the introduction he wrote for the Modern Library edition of Whitman's poems in 1921. But the note that he penned in the 1856 Leaves of Grass is quite revealing.

\section{What a lusty, reckless one was this Young Walt! \\ C.S.}

What an unaccountable oneand how respectable time has now made him!

In the second decade of this century Sandburg's own verse was often deemed lusty, reckless, and perhaps unaccountable. Today, in the 1960's, Sandburg is a revered man of letters. Time has made him, too, respectable.

\section{Kaser Is New Editor of CRL}

Wrrt the March 1963 issue, the editorship of College and Research Libraries returns to Nashville, Tennessee, where it was begun by Dr. A. F. Kuhlman in 1939. The new editor will be Dr. David Kaser, director of the Joint University libraries and professor of library science in Vanderbilt University, George Peabody College, and Scarritt College. Dr. Kaser has been on CRL's editorial board since last year, was on the editorial board of Library Resources and Technical Services from 1958 to 1962, and was editor of the Missouri Library Association Quarterly from 1958 to 1960 . He has also edited The Cost Book of Carey \& Lea, which is presently in the University of Pennsylvania Press. In addition to his editing, Dr. Kaser has authored three books and a score of articles which have appeared in library, bibliography, and history journals.

The new assistant editor will be John D. Batsel, assistant divinity librarian in the Joint University libraries. Mr. Batsel took his baccalaureate degree from Lambuth College, his M.A. in religion and his B.D. degree from Vanderbilt University and received his library training in the Peabody Library School. 